\title{
3D modelling of geological and anthropogenic deposits at the World Heritage Site of Bryggen in Bergen, Norway.
}

\author{
Johannes de Beer $^{\mathrm{a}} *$, Simon J. Price ${ }^{\mathrm{b}}$, Jonathan R. Ford ${ }^{\mathrm{c}}$ \\ ${ }^{a}$ Groundwater Section, Geological Survey of Norway (NGU), P.O. Box 6315 Sluppen, 7491 Trondheim, \\ Norway \\ ${ }^{b}$ British Geological Survey, United Kingdom \\ ${ }^{c}$ British Geological Survey, United Kingdom \\ * corresponding author.E-mail: hans.debeer@ngu.no
}

\begin{abstract}
The landscape of many historic cities and the character of their shallow subsurface environments are defined by a legacy of interaction between anthropogenic and geological processes. Anthropogenic deposits and excavations result from processes ranging from archaeological activities to modern urban development. Hence, in heritage cities, any geological investigation should acknowledge the role of past and ongoing human activities, while any archaeological investigation should be conducted with geological processes in mind. In this paper it is shown that 3D geological and anthropogenic models at different scales can provide a holistic system for the management of the subsurface. It provides a framework for the integration of other spatial and process models to help assess the preservation potential for buried heritage. Such an integrated framework model is thus contributing to a decision support system for sustainable urban (re)development and regeneration in cities, while preserving cultural heritage. A collaborative approach is proposed to enhance research and implementation of combined geological and archaeological modelling for sustainable land use planning and heritage preservation, using York and Bryggen as prime examples. This paper presents the status of 3D framework modelling at Bryggen in Norway as an example.
\end{abstract}

\section{Keywords}

Urban landscape, cultural heritage, subsurface environment, GSI3D ${ }^{\mathrm{TM}}$, 3D modelling, GIS

\section{Introduction}

Sustainable urban planning in heritage cities requires a multidisciplinary approach in order to protect and preserve archaeological heritage and at the same time facilitate viable urban development. This paper illustrates the benefits of easily available and user-friendly 3D geological and anthropogenic modelling tools as part of a decision support system for cultural heritage preservation and sustainable regeneration in heritage cities. It also addresses the need for new and improved classifications for archaeological deposits and their properties, partly through adaptation and extension of available classifications for other types of artificial ground (Ford et al., 2006). Such a classification facilitates deposit and excavation modelling and an objective decision support tool for the management of cultural heritage in-situ. 
The aims are illustrated by presenting early results of the application of 3D subsurface modelling to the assessment of the in-situ preservation potential of cultural deposits at Bryggen in Bergen, Norway.

\section{Cultural deposits as an integral part of the anthropogenic subsurface}

Standing historical buildings often rest on extensive archaeological remains, also known as cultural deposits. Depending on the natural environment, the cultural deposits at many sites consist of highly organic, naturally degradable strata (Holden et al, 2009). Examples are Hungate in York (Kenward and Hall, 2000), Oslo (Schia og Høeg, 1987), Szczecin (Wilgocki, 2005). Preservation conditions for naturally degradable archaeological remains are strongly dependent on both water quality and the presence or absence of groundwater in particular (Van de Noort et al., 2001, Caple, 1996). Deterioration of archaeological material often occurs as a consequence of lowering of the groundwater level (Holden et al, 2006, De Beer and Matthiesen, 2008). Both mechanical settling and oxidisation of organic material occur, destroying archaeological assets and removing the bearing capacity of the historical buildings above (De Beer, 2008). A main goal at such heritage sites is therefore to establish a stable hydrological environment, so the site will be safeguarded for posterity.

Despite the important role of hydrogeology in preservation at many sites, there is still a lack of systematic recording of hydrological, geological and geochemical processes in order to improve in-situ preservation and management of complex archaeological sites. To better understand the preservation conditions and design mitigative measures, it is necessary for any archaeological site to be placed within the context of its wider natural environment. The natural hydrological balance and possible changes that are being forced upon it by nature or humans need to be more thoroughly understood (Holden et al., 2006, 2009).

A better understanding of the environmental context of a complex archaeological site requires a hydrogeological model able to incorporate the physical and chemical processes that affect the preservation of buried archaeological remains, and in which the spatial variation of the environment and its vulnerability is identified. Proper risk assessment and the protection of archaeological heritage requires effective multi-disciplinary collaboration (Holden et al., 2006). Holden et al. (2009) proposed a three-staged approach for collection of hydrological data for archaeological sites in urban contexts. Although the strategy described by Holden et al. is developed for the City of York case, they recognise that the approach has generic applications for urban areas worldwide (Holden et al., 2009, pp. 3201-3202). The strategy proposed by Holden et al. (2009) has been carried out at Bryggen, though not as consecutive stages, but as more or less parallel surveys and studies. This paper focuses on development of an archaeologically meaningful 3D geological and anthropogenic model. 


\section{Classification and characterisation of anthropogenic deposits}

\subsection{Morpho-stratigraphical classification of artificial ground and cultural deposits}

An anthropogenic artificial ground model including cultural layers is only archaeologically meaningful if a sensible classification is made, giving information about for example the origin, historic value, state of preservation and vulnerability to degradation of the layer or artefact. Classification of both morpho-stratigraphical and descriptive features of the cultural layers and the burial environment are needed for a proper risk-assessment.

The British Geological Survey (BGS) has developed a classification for "artificial ground" (McMillan et al., 1999, Price et al., 2004, Ford et al., 2006) to improve characterisation of artificial ground for better risk assessment and urban planning (Culshaw, 2005). Cultural layers or excavations and their natural or man-made surroundings can be seen as a special type of artificial ground.

Ford et al. (2006) devised an enhanced Artificial Ground classification scheme following the classification scheme of Rosenbaum et al. (2003) and McMillan et al. (1999). It is based on the genetic origin of the feature and its morphology in response to the increasing need for classifying man-made landforms in the context of ground conditions, geohazards and landscape evolution. The scheme is structured as a three-tier hierarchy using Class, Type and Unit to describe in progressively more detail the origin and landform of the deposit or excavation. It provides a flexible and logical subdivision of landforms essentially based on morpho-stratigraphical characteristics that could be extended with archaeological features. An example of the classification is given in figure 1.

Archaeological Artificial Ground may be of the Class Made, Worked or Landscaped Ground within the enhanced classification system. Ford et al. (2006) suggest that further subdivision of these classes may be related directly to the English Heritage classification (http://thesaurus.english-heritage.org.uk) to avoid duplication and ensure compatibility. The English Heritage classification is based on national heritage documentation and could, with moderate modifications, be used for 2D and 3D mapping within the UK. Regrettably, an international heritage classification system does not exist, though it would be of great benefit for systematic mapping purposes and international comparison of landscapes and archaeological sites.

Table 1 shows selected examples of subdivisions of Made Ground and Worked Ground from the enhanced classification system for Artificial Ground as proposed by Ford et al. (2006). Two archaeological Types have been added to the table, with some suggestions for further subdivision down to Unit-level. 
Ford et al. (2006) suggested using the Unit-level, with the highest level of detail, on geological surveys on 1:10,000 scales or greater. For mapping of archaeological features, the used scale is often much less than 1:10,000. Archaeological documentation of (buried) domestic layers is carried out at a decimetre scale down to the level of individual artefacts. For archaeological preservation management and multidisciplinary communication, mapping of features on the Type- or Unit-level on a relatively large scale will usually be sufficient. It may however be of benefit for archaeologists to further subdivide the Unit-level down to individual structures or artefacts (e.g. bath house, cabin etc.), or to subdivide the Type-level in the case of archaeological excavations (archaeological pits, ditches, ponds, wells, etc.) for documentation purposes on site maps or in 3D models at scales of 1:1,000 and greater.

\subsection{Use of descriptive features}

The classification scheme proposed by Ford et al. (2006) does not provide a classification for the material comprising artificial ground, i.e. the descriptive component-based soil and rock classifications (including grain size, or mineral distributions). A corresponding classification of descriptive attributes of anthropogenic material, such as geotechnical and hydraulic characteristics, would add considerable value to the scheme. From an archaeological perspective, a standardised documentation and classification of descriptive characteristics, e.g. the state of preservation or age of (parts of) a cultural deposit, would similarly be of benefit for mapping, site comparison and risk assessment for archaeological sites (Holden et al., 2006, 2009). For mapping purposes, chrono-stratigraphically described features within an archaeological deposit, such as age-related remnants of significant landscaping events (e.g. fire layers) can be used to describe morpho-stratigraphical features. In addition to traditional stratigraphical divisions based on lithological or morphological characteristics, one can then directly visualise other surfaces, such as the transition between medieval and post-medieval deposits.

Descriptive features that are not of chrono-stratigraphical character (e.g. grain size distributions, chemical composition or the state of preservation), as well as features that are practically independent of the artificial ground itself, but describe the surrounding and burial environment (e.g. groundwater level, temperature and quality), form a challenge in mapping and modelling. In this paper, we propose a descriptive parameter that documents and classifies the state of preservation of archaeological deposits, the preservation category, to be used in deposit models. Secondly, suggestions are made on how to include measured and modelled groundwater levels.

\subsection{The preservation category}

The Norwegian government considers archaeological strata a non-renewable resource (Norwegian Ministry of the Environment, 2005, 2008) and direct or indirect damage to them poses a threat to continued in-situ preservation (Malta Convention, 1992). The medieval towns are protected under the provisions of Norway's Cultural Heritage Act. Recently, the Directorate for Cultural Heritage, Riksantikvaren - in close cooperation with the Norwegian Institute for Cultural Heritage Research, Norsk Institutt for Kulturminneforskning (NIKU) 
and other relevant institutions - has developed a Norwegian Standard (2009) that stipulates various requirements concerning environmental monitoring and investigation of cultural deposits. One of the requirements is the use of the state of preservation scale (SOPS) for archaeological layer recording, thereby classifying each documented sample in a preservation category.

For layer (/context) recording in connection with both excavation and drilling, and particularly with a view to subsequent monitoring, mapping and modelling work, Riksantikvaren and NIKU use a recording sheet described in "The Monitoring Manual" (Marstein et al., 2007). This sheet has been developed in recognition of the fact that comparative studies between sites/towns depend on congruent data, and that such data can only be achieved through uniformity of documentation (Dunlop, 2006). One of the most important fields in this documentation is the preservation category, intended to be an (ideally) absolute scale that allows the degree of preservation to be assessed and compared both over time and between locations. The state of preservation for each individual deposit is determined by the archaeologist by means of a range of criteria such as odour, colour, the amount of force needed to snap or pull apart organic material, the sponge reaction of soil, and general appearance. The correct preservation category is then found by reference to the state of preservation scale, as shown in table 2 .

Although one clearly may discuss the validity of "forcing" individual archaeologists" observations into an absolute scale, the preservation category can be used as a more or less unique descriptive attribute of the intrinsic "value" of an archaeological layer and can be used to assess the need for protection or mitigation measures. More quantitative measurements from geochemical analyses, such as loss-on-ignition (LOI) values can be used, to a certain extent, to "calibrate" the assessment of the archaeologist. Specific geochemical analyses may also be used in combination to determine the preservation conditions of the environment in which an archaeological feature is buried. As preservation conditions are partly dependent on the degradation properties of archaeological remnants, it will be necessary to have multiple categories based on the degradation processes associated with the various kinds of material. An overview of degradation processes for different materials together with approaches and methods for the assessment and monitoring of archaeological sites in situ, is given in Huisman (ed.) (2009). This may provide a good starting point for further categorisation, documentation and mapping purposes in order to assess the state of preservation of an archaeological site and its burial environment.

\section{Characterisation and 3D modelling of cultural and other anthropogenic deposits at the World Heritage Site of Bryggen in Bergen}

\subsection{Site description}

Bryggen in Bergen is one of the oldest trading ports in northern Europe, and the location of one of the Hanseatic League's four overseas offices. The buildings date from shortly after the 
major fire of 1702, but have a pre-Hanseatic building structure dating back to the $11^{\text {th }}$ century. A historical map of the area around Bryggen showing important hydrogeological features such as former drainage patterns and the shoreline during the early Middle Ages is shown in Fig. 2.

In 1955, a large fire at the western part of Bryggen destroyed about a third of the historic buildings. Extensive archaeological excavations at the burnt plot took place in the period from 1955 to 1968 (Herteig, 1985). In 1979, Bryggen was included in UNESCO's World Heritage list. The total system comprising Bryggen, including underground archaeological remains plus 61 buildings, i.e. from the underlying bedrock to the rooftops, is a considered a single cultural monument.

After the archaeological excavations were completed, a hotel with underground parking was constructed in 1979, west of the remaining part of Bryggen. Today, low phreatic groundwater levels and increased flux of oxygen in the subsurface, leading to decomposition of organic archaeological deposits and subsequent settling are an acute threat to Bryggen. The problems are primarily caused by changed ground conditions (De Beer, 2008, De Beer and Matthiesen, 2008). To avoid constructional damage of the building due to high groundwater pressures, a drainage system was constructed below the subsurface hotel parking. Although the hotel and drainage system is enclosed by a wall of sheet piling, it has lowered groundwater levels considerably in the surrounding area, particularly at the rear of Bryggen, where loss of organic material has led to current settling rates up to $8 \mathrm{~mm}$ per year (Jensen and Stordal, 2004).

A large restoration project is running from 2001 to 2021, covering all the buildings and their foundations. This strategic project aims to bring Bryggen to a state of repair that is in accordance with its status as a World Heritage Site, and where no more than an ordinary level of building maintenance is necessary. More details on the history of Bryggen are given in Christensson et al. (2004).

\subsection{Archaeology}

Below the historic buildings lie cultural deposits covering the entire span of Bryggen's history. At Bryggen, the cultural deposits comprising constructions and artefacts add up to a thickness exceeding eight metres in places, with 10 or more separate building phases often built one on top another. A "typical" sequence consists of layers with high organic content interspersed with fire layers, the latter being the remains of the many fires that struck Bergen in medieval and later times. Today's policy for Bryggen is not to excavate, but to leave much of the cultural deposits as possible for future generations, in line with the Valetta treaty and Norwegian national policy (Malta Convention, 1992, Norwegian Ministry of the Environment 2005, 2008). This implies the survival of all the evidence preserved in the cultural deposits through the maintenance of the physical, chemical and hydrogeological conditions that resulted in its preservation. 


\subsection{Hydrogeology}

The hydrogeological situation of the site is characterised by its position along the Vagen harbour, just beneath a mountain slope. The regional groundwater level is topographically controlled with regional groundwater flow towards the harbour. The regional phreatic level and hydraulic heads in deeper geological formations depend on the amount of precipitation, the infiltration capacity and the hydraulic characteristics of the underlying natural sediments, cultural deposits and bedrock (De Beer, 2005, 2008). Bryggen is located on the regional geological formation called the "Bergen Arc" consisting of greenstones, phyllites and gneisses with a low primary hydraulic conductivity (Fossen, 1989, Fossen and Ragnhildstveit, 2008). However, high water-bearing features such as zones of weakened bedrock, open faults and joints are frequent (Ellingsen, 1987). Under the World Heritage Site, the bedrock surface occurs at about $12 \mathrm{~m}$ below sea level, rising gradually to about $2 \mathrm{~m}$ below sea level at the north-eastern side of Bryggen. Old beach sands partly cover the bedrock directly or in other places cover an intervening layer of glacial till. The wooden buildings were originally built on the beach along the shoreline.

Although the regional groundwater flow direction is south-west, towards the harbour, the local groundwater levels and chemistry are influenced by a complex interaction of multiple factors such as meteorology and infiltration capacity, local hydraulic variations, tidal variations, salt water intrusion, artificial drainage systems and underground infrastructure (De Beer and Matthiesen, 2008).

\subsection{Monitoring programmes}

Documentation of the state of preservation and monitoring of the preservation conditions of the burial environment at Bryggen has been ongoing since 2001. The monitoring covers both the saturated and unsaturated zone and includes detailed chemical analysis of water and soil samples, continuous logging of piezometric head, oxygen and soil moisture content, measurements of movement rates for both buildings and soil surface, field measurements in test pits, as well as studies of archaeological material and modern samples left in the soil for a few years. It has been found that preservation conditions within the two-hectare study area vary considerably, from excellent to very bad preservation conditions, as well as intermediate zones with less ideal preservation conditions (Matthiesen, 2007).

In order to better understand and quantify the water balance and to identify factors influencing the phreatic levels at Bryggen, numerical groundwater modelling has been used in conjunction with field monitoring and laboratory analyses. The use of groundwater modelling in parallel with traditional monitoring enables continuous adjustment and improvement of the monitoring strategy, thereby improving both the understanding of the hydrogeological system as well as giving feedback to the numerical model describing the system more adequately. Ultimately, the numerical model can then be used as a tool to predict temporal and spatial changes in hydraulic head and phreatic levels and thereby identify zones that may be or become at risk of in situ decay (De Beer and Matthiesen, 2008). Results of the monitoring programmes and numerical groundwater modelling are presented in 
various publications (Matthiesen et al., 2006, Matthiesen 2007, De Beer, 2008) and are not further discussed here.

\subsection{D subsurface framework modelling}

The complexity of the Bryggen archaeological site, as well as the large amounts of monitoring and modelling data from multidisciplinary sources that are being gathered, have called for an easy-to-use visualisation and framework modelling system of the underground in three dimensions. A portrayal of multidisciplinary data from archaeological, geochemical and hydrological monitoring and modelling within in an interrogative 3D subsurface modelling framework of the site and its wider surroundings, contributes to a holistic site evaluation and better risk assessment. Cultural heritage authorities will be equipped with model outputs that enable them to better assess and communicate risks of in-situ decay at the site. A 3D framework model will facilitate communication between different stakeholders. As a World Heritage Site and one of Norway's main tourist attractions, stakeholders vary from cultural heritage authorities at national, regional and local levels, spatial planners, municipal services, building- and shop-owners, to the general public.

A framework model of the underground at the Bryggen site has been constructed using proprietary software GSI3D (Geological Surveying and Investigations in 3 Dimensions), produced by Insight GmbH (Hinze et al. 1999, Kessler and Mathers, 2004, Mathers and Kessler, 2010) and described by Culshaw (2005). GSI3D not only produces detailed 3D geological models, but bulk-attributed models with physical, chemical, hydrogeological or archaeological parameters. Once an attributed model is completed, a large number of customised geoscientific outputs can be generated with little computation. One of the main advantages of this system lies in the ability to build and visualise 3D models on a standard desktop PC without the need for expensive and operationally complex computer software, such as numerical groundwater modelling software. It can therefore be used by a far wider group of users than specialist numerical modellers whilst generating outputs that can be integrated with numerical hydrological models.

The Bryggen subsurface framework model was constructed using the following workflow:

a) Data preparation and definition of a general vertical stratigraphy.

b) Borehole import and bulk attribute definition of stratigraphy, lithology and archaeology.

c) Construction of correlated and synthetic sections.

d) Construction of spatial distribution "envelopes" of geological and anthropogenic units.

e) Calculation of a full subsurface 3D framework model.

f) Import of parameter values for the boreholes, such as preservation state, groundwater levels and chemical analyses.

g) Import of other calculated and modelled surfaces, such as (modelled) groundwater table.

h) Interrogation of the subsurface framework model by creating synthetic slices, sections and $3 \mathrm{D}$ visualizations. 
Data preparation (a) included definition of a generalized vertical stratigraphy for the model area, as well as the preparation of files containing borehole locations, descriptions and parameters. Borehole import and bulk attribution $(b)$ was carried out by importing the standard recording sheets from each of the archaeologically supervised boreholes. GSI3D visualizes these as "borehole sticks" at the correct spatial location. Documentation sheets of the boreholes not only describe stratigraphy and lithology of natural and cultural layers (similar to geological formations), but also subdivisions within a cultural layer, based on distinctive archaeological characteristics.

A number of sections were manually correlated (c), using the borehole sticks as correlation points, along with available geological maps, known outcrops and construction of underground infrastructure. In addition, synthetic sections were added to constrain later full model calculation. A number of the latter sections are not based on actual field data (e.g. by boreholes or geophysical measurements), but are merely based on expert judgement, thus capturing the conceptual ideas of the modeller. An overview of the constructed sections is shown in Fig. 3.

The spatial distribution of the geological and anthropogenic layers was subsequently defined by constructing distribution "envelopes" $(d)$. The envelopes represent the maximum spatial distribution of each stratigraphic unit. At the ground surface, the superposition of envelopes according to their stratigraphic sequence (youngest at the top) equals the geological map. The modelling software calculates a full 3D model $(e)$ by mathematical interpolation of the correlated and synthetic sections combined with the distribution envelopes. Once the full 3D framework model has been calculated, it can be interrogated for areas and volumes, as well as sliced horizontally and vertically at any location in the model $(h)$.

The subsurface model for Bryggen is shown in an "exploded" view in Fig. 4. The cultural deposits are shown here in one colour and schematised as one bulk attributed stratigraphical layer. However, based on the detailed information from the archaeological drillings, the cultural layers can be subdivided and coloured based on for example age, structure or other characteristics, provided that these are chrono-stratigraphical attributes.

At most drilling positions, the archaeological documentation provides the preservation state for the individual cultural layers (Dunlop, 2008a, b, c, 2009a, b, 2010). The preservation category is usually assessed on a high vertical resolution $(0.20 \mathrm{~m})$ within a sequence of cultural layers. The preservation category is added to the framework model ( $f$ ) as "intraformational" information and visualized using borehole-sticks. The state of preservation differs from one location to the other, as well as with depth, generally following the preservation conditions of the burial environment. It is therefore difficult to extrapolate this descriptive attribute in 3 dimensions. The borehole sticks can be visualised individually in the GSI3D borehole-viewer, in all 3D outputs and in sections. Fig. 5 shows a three dimensional 
section view of the model, with borehole sticks colour-coded according to the state of preservation.

A wide range of data can be shown this way, such as lithology, strength or density descriptions, water level data, geotechnical, geophysical, geochemical and archaeological parameters. Up to four different attributes can be presented in sections and borehole logs. At Bryggen, ground and groundwater samples are analysed for a range of chemical parameters that are indicators for preservation conditions (e.g. chloride, sulphate, oxygen, LOI). Concentrations of the chemical parameters, with their individual sampling depths, have been added to the subsurface framework model database $(f)$. Colour legends were created to visualise concentration classes in the borehole sticks.

Fig. 6 shows a borehole at Bryggen in the GSI3D borehole-viewer with stratigraphical subdivision, saturation conditions, preservation category and chloride content. The borehole saturation parameter is based on calculated low (5-percentile) and high (95-percentile) groundwater levels measured with automatic data loggers. Multiple parameters can also be visualized in boreholes plotted on vertical sections (Fig. 7).

Besides point data, any surface can be added to the subsurface framework model as raster or triangulated irregular network (TIN) files, and independently visualized or used as a surface for calculation purposes $(g)$. Fig. 8 shows the representative annual lowest groundwater table at Bryggen and close surroundings within a 3D section view. Use of contour lines and transparency enable clear visualization of flow direction and comparison with the subsurface deposits. Cultural layers above the groundwater table are at risk of decay. The full 3D subsurface framework model can be "sliced" at the groundwater level and volumes of cultural deposits above (at risk) and below (not at risk) the groundwater level can be calculated.

Fig. 9 shows a map of the total thickness of the cultural layers as calculated by the subsurface model for Bryggen. Here, the model results were exported to GIS for visualization and combination with other data.

This map shows that the cultural layers within the area surrounded by sheet piling are completely removed in the rear part (northeast), but that there is still 0.5 to $3.0 \mathrm{~m}$ left at the front part (southwest). As the cultural layers generally have a very low hydraulic permeability, the remaining thickness is not only relevant from an archaeological point of view, but essential from a hydrological and thus potential in-situ decay perspective. At locations where the cultural layers are removed and replaced by more permeable material, risk of preferential flow paths as well as reduced hydraulic pressure may occur, influencing a much wider area than the physical disturbance itself. If the cultural layers within the area surrounded by sheet piles at Bryggen had not been partly removed, or if they had been 
replaced by low permeable material, the groundwater levels would not have dropped as much and the influenced area would have been considerably less.

A quantitative understanding of the variability of the subsurface geological and anthropogenic deposits and their properties is necessary to perform a full spatial risk assessment of in-situ decay at the Bryggen site and other archaeological sites. The current subsurface framework model provides a tool to obtain and communicate this quantitative understanding. The spatial distribution of geological, archaeological and other anthropogenic deposits and structures is currently included in the framework model. A full risk assessment however, requires inclusion of multiple, and partly dynamic, property data, such as:

- Permeability distribution; e.g. areas with low permeable till below the cultural layers will have less potential risk of in-situ decay than areas where cultural layers are underlain by high permeable beach sands.

- Groundwater temperature distribution; urban heating and/or bacterial decay effects.

- Distribution of environmental chemical parameters; e.g. alkalinity, sulphate and chloride.

- Potential long-term changes in groundwater quantity and quality due to climate change or urban development; e.g. sea level rise.

The inclusion of (dynamic) property data presents a challenge. If the subsurface model is to be used as part of a decision support tool, it needs to be able to identify problematic groundand environmental conditions for mitigation against engineering plans, as well as to quantify potential impacts of urban development on archaeological heritage. It then also provides a communication and visualisation tool to facilitate archaeologists working with in-situ preservation and archaeological risk assessment of the site. Urban planning and cultural heritage authorities will be able to use model output in development and protection plans.

Development and protection plans can for example contain synthetic slices at different depths below the ground level in order to show the subsurface ground distribution, including vulnerable cultural layers. Fig. 10 shows surfaces at 12, 8, 4 and $2.5 \mathrm{~m}$ below average sea level for the Bryggen subsurface model. The resultant surfaces can be used to predict the presence or absence of cultural layers.

\section{Summary and conclusions}

The landscape of many cities and the character of their shallow subsurface environments are defined by a legacy of interaction between anthropogenic and geological processes, as illustrated in this paper by the example of the World Heritage Site of Bryggen in Bergen, Norway. Anthropogenic deposits and excavations result from processes ranging from historical archaeological activities to modern development and urbanisation. The variability of physical, chemical and hydrogeological properties in the subsurface is a function of both natural and human processes. Hence, in heritage cities, any geological investigation should acknowledge the role of past and ongoing human activities, while any archaeological investigation should be conducted with geological processes in mind. 
At Bryggen 3D subsurface framework modelling has been used to provide insights into geological, archaeological and other anthropogenic deposits and structures above and below the ground. 3D modelling at Bryggen is used to explain the vulnerability of the archaeological deposits in their complex interplay with the natural and anthropogenic environments to a variety of stakeholders like urban planners, heritage authorities and the general public. A numerical groundwater model was created to understand spatial and temporal hydrogeological variations and their potential impact on archaeological preservation. Results can be imported in the 3D subsurface framework model for assessment together with other information. As an exemplary case, the Bryggen project illustrates emerging new possibilities of pulling complex (model and monitoring) data from different disciplines together and visualising them in three dimensions. The attributed 3D framework model provides a platform for this data integration and allows portrayal of the heterogeneity of real underground environments. Although further work is needed to model the full heterogeneity of the underground and its properties, intra-formational information can be visualised by using "borehole sticks" spatially registered within the model.

Systematic development of 2D maps and 3D models will require classification of the elements to be documented at different scales. The enhanced classification for artificial ground as proposed by Ford et al. (2006) is a good system for mapping artificial ground, including archaeological deposits. It needs to be further developed by enabling an association with a classification of archaeological features up to a scale of 1:1,000 and higher, corresponding with the usual documentation scale of archaeological investigations.

3D geological models can provide the regional environmental context with which to characterise the spatial and temporal relationships between natural and anthropogenic earth systems. Integration of geological and anthropogenic models of different scales can provide a holistic system for the management of the subsurface. The framework for mapping for 3D modelling provided by GSI3D is flexible and practically scale-independent, which provides opportunities for use in detailed archaeological investigations, as shown by the Bryggen example. This facilitates for the integration of other spatial and process models to help assess the preservation potential for buried heritage, thus contributing to a decision support system for sustainable urban development and regeneration in cities.

\section{Acknowledgements}

The monitoring work at Bryggen is financed by the Directorate for Cultural Heritage in Norway, Riksantikvaren. This paper is part of a research programme on groundwater and cultural heritage, financed by the Geological Survey of Norway and Riksantikvaren. Contributions and comments by Henning Matthiesen (National Museum of Denmark), Marcin Gładki (Hordaland County Council), Rory Dunlop (NIKU) and Ann Christensson (Riksantikvaren) are highly appreciated, as are the comments of reviewers. Simon J. Price and Jonathan R. Ford publish with the permission of the Executive Director, British Geological Survey, Natural Environment Research Council. 


\section{References}

Caple, C., 1996. Parameters for monitoring anoxic environments. In: Corfield, M., Hinton, P., Nixon, T., Pollard, M. (Eds.), Preserving Archaeological Remains in Situ. Museum of London Archaeology Service, London, pp. 113-123.

Christensson, A., Paszkowski, Z., Spriggs, J.A., Verhoef, L. (Eds.), 2004. Safeguarding historic waterfront sites. Bryggen in Bergen as a case study. 1st edition. Stiftelsen Bryggen and Polytechnika Szczecinska, Bergen, Norway.

Culshaw, M.G., 2005. From concept towards reality: developing the attributed 3D geological model of the shallow subsurface. Quarterly Journal of Engineering Geology and Hydrogeology, 38, pp. 231-284.

De Beer, J., 2008. Statusrapport grunnvannsovervåking og hydrogeologisk modellering ved Bryggen i Bergen. Report 2008.069 (in Norwegian only).

De Beer, J., Matthiesen, H., 2008. Groundwater monitoring and modelling from an archaeological perspective: possibilities and challenges. NGU Special Publication 11, pp. 6781 .

Dunlop, A.R., 2006. Archaeological recording in connection with monitoring in Norways medieval towns. Conference proceedings, Preserving Archaeological Remains in situ 3, VU University, Amsterdam, the Netherlands.

Dunlop, A.R., 2008a. The Bryggen Monitoring Project, Part 2: Archaeological investigations in connection with monitoring project, Bredsgården tenement, Bryggen, Bergen, 2002-3. NIKU Arkivrapport 66/2008, Bergen, Norway.

Dunlop, A.R., 2008b. The Bryggen Monitoring Project, Part 4: report on the archaeological investigation of five dipwell boreholes, 2005. NIKU Arkivrapport 28/2008, Bergen, Norway.

Dunlop, A.R., 2008c. The Bryggen Monitoring Project, Part 5: report on the investigations at the rear of Nordre Bredsgården, 2006. NIKU Arkivrapport 22/2008, Bergen, Norway.

Dunlop, A.R., 2008d. The Bryggen Monitoring Project, Part 6: report on the archaeological investigation of three dipwell boreholes, 2006. NIKU Arkivrapport 63/2008, Bergen, Norway.

Dunlop, A.R., 2008e. The Bryggen Monitoring Project, Part 7: report on the archaeological investigation of five dipwell boreholes, 2007. NIKU Arkivrapport 64/2008, Bergen, Norway.

Dunlop, A.R., 2009a. The Bryggen Monitoring Project, Part 8: report on the archaeological investigation of two dipwell boreholes, Holmedalsgården and Svensgården, 2009. NIKU Oppdragsrapport 43/2009, Bergen, Norway.

Dunlop, A.R., 2009b. The Bryggen Monitoring Project, Part 9: report on the archaeological investigation of two dipwell boreholes, Schøtstuene, 2009. NIKU Oppdragsrapport 222/2009.

Dunlop, A.R., 2010.The Bryggen Monitoring Project, Part 10: report on the archaeological investigation of three dipwell boreholes, Bugården/Bredsgården, Bryggen, 2009. NIKU Oppdragsrapport 36/2010, Bergen, Norway. 
Ellingsen, 1987. Beskrivelse til hydrogeologisk kart 1115 I, 1:50.000, Geological Survey of Norway. Rapport 24 (342), Universitetsforlaget.

Ford, J., Kessler, H., Cooper, A.H., Price, S.J., Humpage, A.J., 2006. An enhanced classification for Artificial Ground. British Geological Survey internal report, IR/04/38.

Fossen, H., 1989. Geology of the Minor Bergen Arc, West Norway. NGU-bulletin 416.

Fossen, H., and Ragnhildstveit, J., 2008. Berggrunnskart Bergen 1115 I, 1:50.000. Geological Survey of Norway.

Herteig, A.E., 1985. The archaeological excavations at Bryggen, "the German wharf", in Bergen, 1955-68: excavation, stratigraphy, chronology, field-documentation.

Universitetsforlaget, Oslo, Norway.

Hinze, C., Sobisch, H., Voss, H., 1999. Spatial modelling in geology and its practical use. Fortschritte Der Geoinformatik = Progress in Geoinformatics, pp. 51-60.

Holden, J., West, L.J., Howard, A.J., Maxfield, E., Panter, I., Oxley, J., 2006. Hydrological controls of in situ preservation of waterlogged archaeological deposits: Earth-Science Reviews 78, pp. 59-83.

Holden, J., Howard, A.J., West, L.J., Maxfield, E., Panter, I., Oxley, J., 2009. A critical review of hydrological data collection for assessing preservation risk for urban waterlogged archaeology: A case study from the City of York, UK. Journal of Environmental Management 90, pp. 3197-3204.

Huisman, D.J. (Ed.), 2009. Degradation of archaeological remains. Sdu Uitgevers b.v., Den Haag, the Netherlands.

Jensen, J.A., Stordal, A.D., 2004. Miljøovervåkningsprosjekt Bugården - Bryggen i Bergen FoU-prosjekt. Grunnundersøkelser og setningsmålinger. Multiconsult report 400962 - 1, Bergen, Norway.

Kenward, H.K. and A.R. Hall, 2000. Decay of delicate organic remains in shallow urban deposits: are we at a watershed?, Antiquity 74 (2000), pp. 519-525.

Kessler, H., Mathers, S.J., 2004. Maps to models. Geoscientist 14, pp. 4-6.

Lelliott, M., Bridge, D.M., Kessler, H., Price, S.J., Seymour, K.J., 2006. The application of 3D geological modelling to aquifer recharge assessments in an urban environment. Quarterly Journal of Engineering Geology \& Hydrogeology 39, pp. 293-302.

Malta Convention, 1992. The European convention about protection of the archaeological heritage. European Treaty series no 143. Council of Europe, Valetta 16. January 1992.

Mathers, S.J., Kessler, H. 2010. GSI3D - Version 2.6. User Manual. British Geological Survey Open report OR/10/007, United Kingdom. http://gsi3d.com

Marstein, N., Paludan-Müller, C., Loska, A., Christensson, A., Dunlop, A.R., Molaug, P.B., Reed, I.W., Edvardsen, G., Jensen, J.A., Matthiesen, H., Ringsted, J.P., Nilsson, T., Martens, V., Risan, T., Eriksson, J.G., 2007. The Monitoring Manual. Procedures \& Guidelines for the 
monitoring, recording and preservation/management of urban archaeological deposits. http://www.riksantikvaren.no/filestore/Veileder_komp.pdf

Matthiesen, H., Dunlop, R., Jensen, J.A., De Beer, J., Christensson, A., 2006. Monitoring of preservation conditions and evaluation of decay rates of urban deposits - results from the first five years of monitoring at Bryggen in Bergen. Conference proceedings, Preserving Archaeological Remains in situ 3, VU University, Amsterdam, the Netherlands.

Matthiesen, H., 2007. Preservation conditions of urban deposits studied through detailed chemical analysis of ground water from Bryggen in Bergen. Journal of Archaeological Science 35, pp. 1378-1388.

McMillan, A.A., Powell, J.H., Evans, C.D.R., Irving, A.A.M., Merritt, J.W., Morigi, A.N., Northmore, K.J., 1999. Classification of artificial (man-made) ground and natural superficial deposits applications to geological maps and datasets in the UK. British Geological Survey, Report RR/99/004, United Kingdom.

Norwegian Ministry of the Environment, 2005. St.meld. nr. 16 (2004-2005). Leve med kulturminner (in Norwegian).

Norwegian Ministry of the Environment, 2008. The Government's Environmental Policy and the State of the Environment in Norway. Excerpts in English: Report. No. 26 (2006-2007) to the Storting.

Price, S.J., Burke, H.F., Terrington, R.L., Reeves, H.J., Boon, D.P., Scheib, A.J., 2010. The $3 \mathrm{D}$ characterisation of the zone of human interaction and the sustainable use of underground space in urban and peri-urban environments: case studies from the UK. Zeitschrift Der Deutschen Gesellschaft Fur Geowissenschaften 161, pp. 219-235.

Price, S.J., Ford, J.R., Kessler, H., Cooper, A.H., Humpage, A.J., 2004 Artificial ground: mapping our impact on the surface of the Earth. Earthwise 20, pp. 30-31.

Rosenbaum, M.S., McMillan, A.A., Powell, J.H., Cooper, A.H., Culshaw, M.G., Northmore, K.J., 2003. Classification of artificial (man-made) ground. Engineering Geology 69, pp. 399409.

Royse , K.R., Rutter, H.K., Entwisle, D.C., 2009. Property attribution of 3D geological models in the Thames Gateway, London: new ways of visualising geoscientific information. Bulletin of Engineering Geology and the Environment 68, pp. 1-16.

Schia, E., and Høeg, H.I., 1987. "Søndre felt": stratigrafi, bebyggelsesrester og daterende funngrupper. De Arkeologiske utgravninger i Gamlebyen, Oslo, bind 3.

Standard Norge, 2009. Kulturminner. Krav til miljøovervåking og -undersøkelse av kulturlag. NS 9451:2009, Lysaker, Norway (in Norwegian only).

Van de Noort, R., Fletcher,W., Thomas, G., Carstairs, I., Patrick, D., 2001. Monuments at Risk in England's Wetlands. University of Exeter, Exeter.

Wilgocki, E., 2004. Wooden constructions found during archaeological excavations at Podzamcze area in Szczecin. In: Christensson, A. et al., 2004. Safeguarding historic 
waterfront sites. Bryggen in Bergen as a case study. 1st edition. Stiftelsen Bryggen and Polytechnika Szczecinska, Bergen, Norway. 


\section{$\begin{array}{lll}\text { CLASS } & \text { TYPE } & \text { UNIT }\end{array}$}
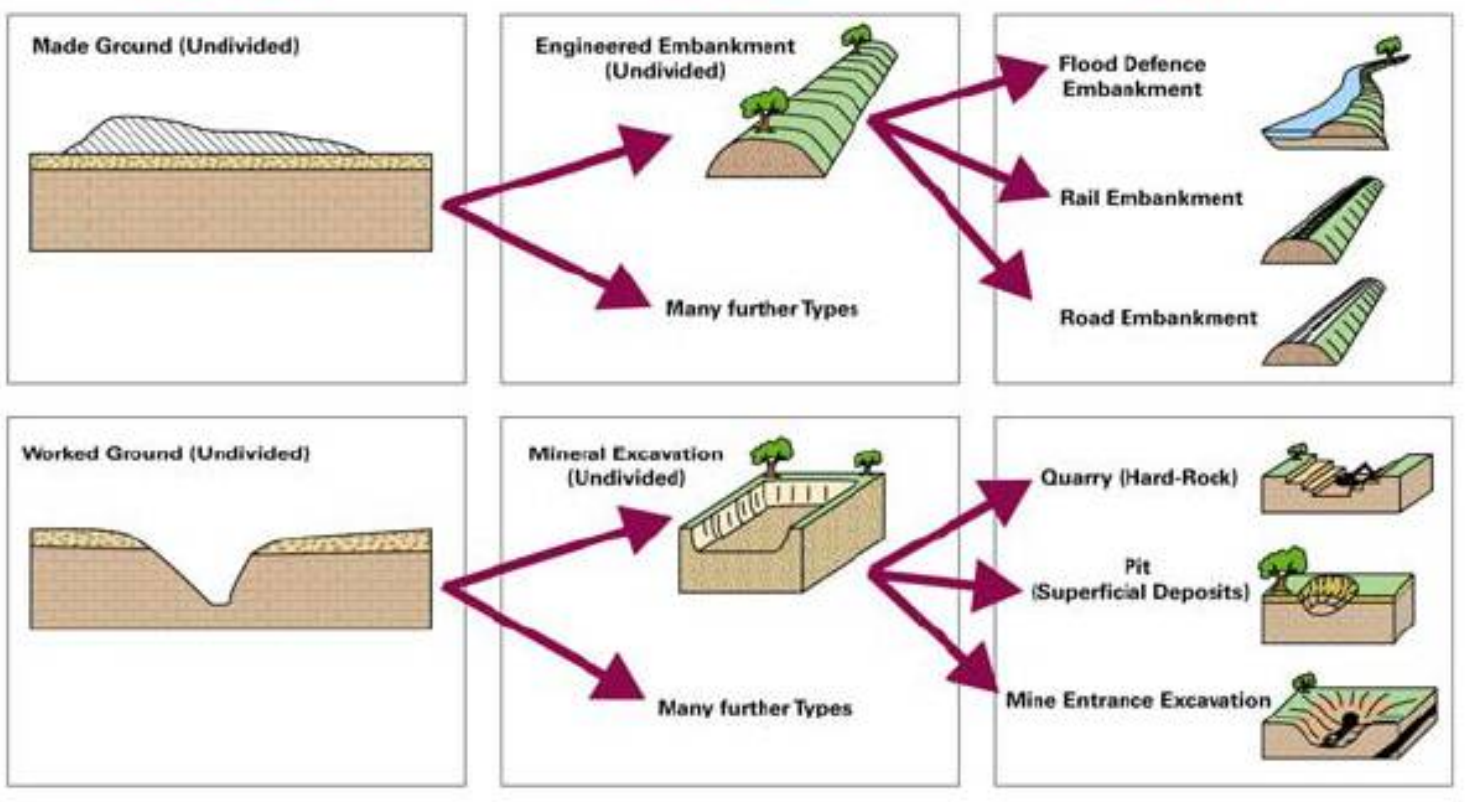

FIGURE 1: Selected examples of branches of the Artificial Ground hierarchy (Ford et al., 2006)

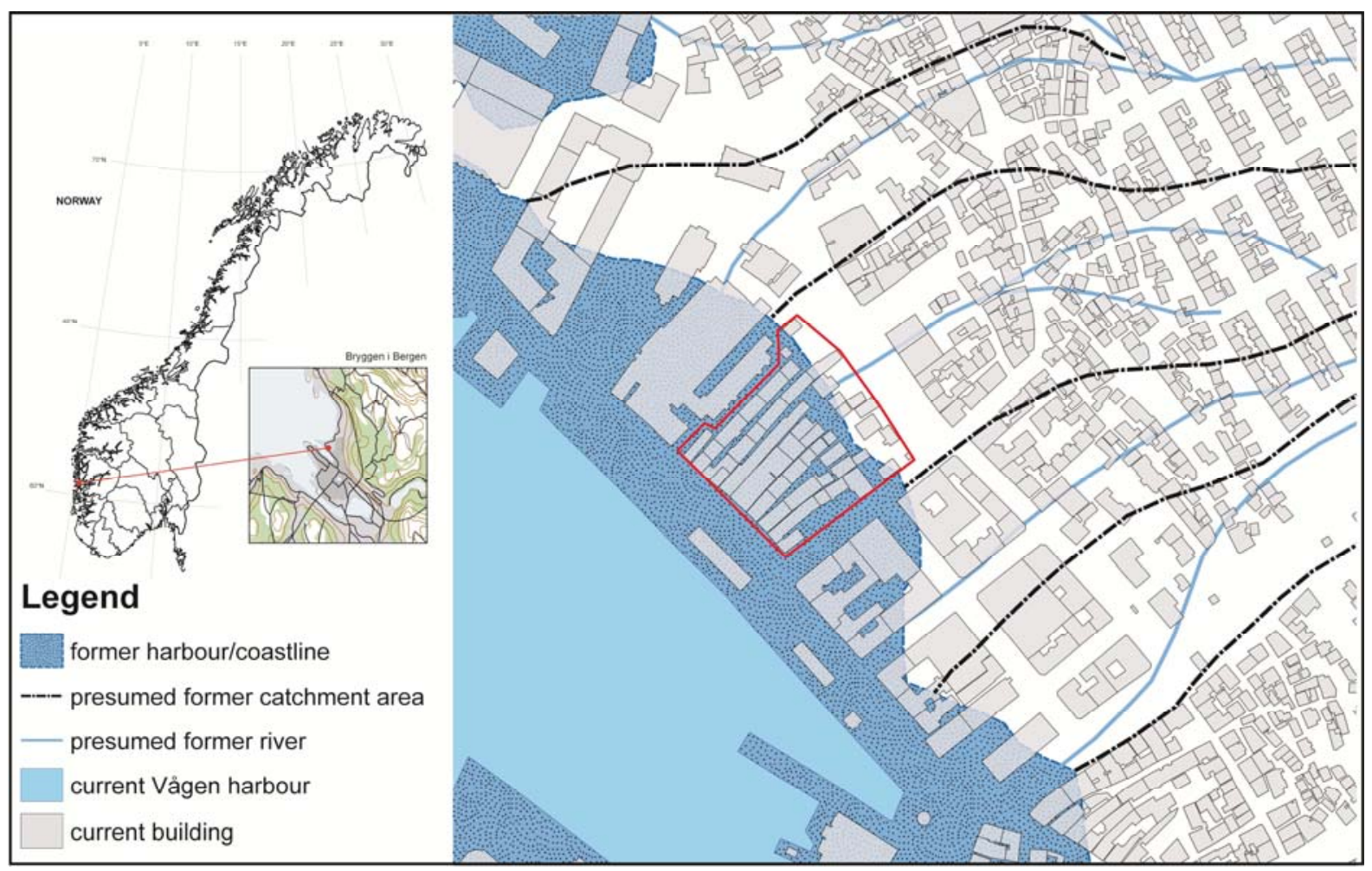

FIGURE 2: Map of Bryggen and surroundings with historical hydrogeological features. 


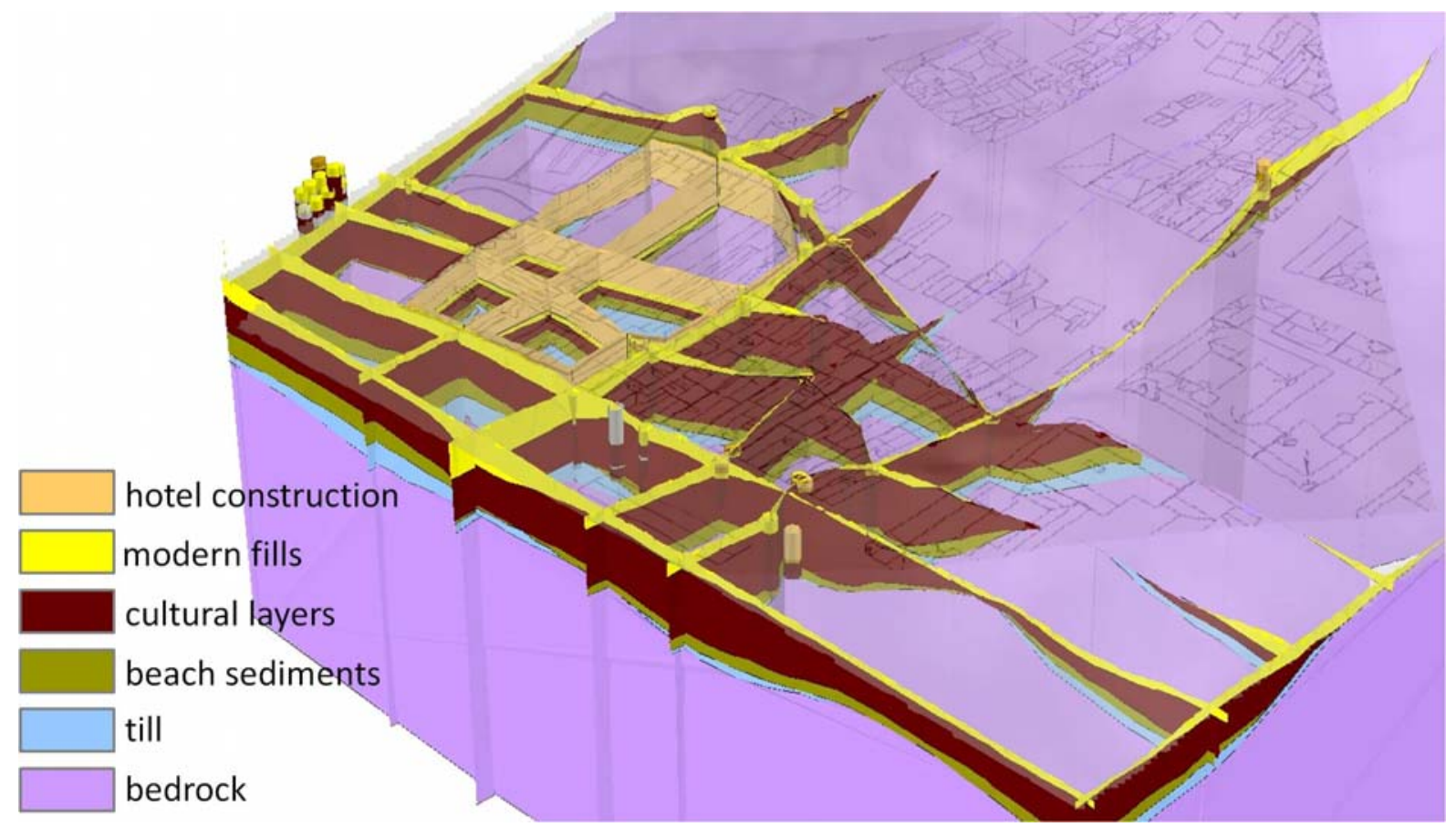

FIGURE 3: Constructed model sections (GSI3D) including borehole sticks with stratigraphical attributes.
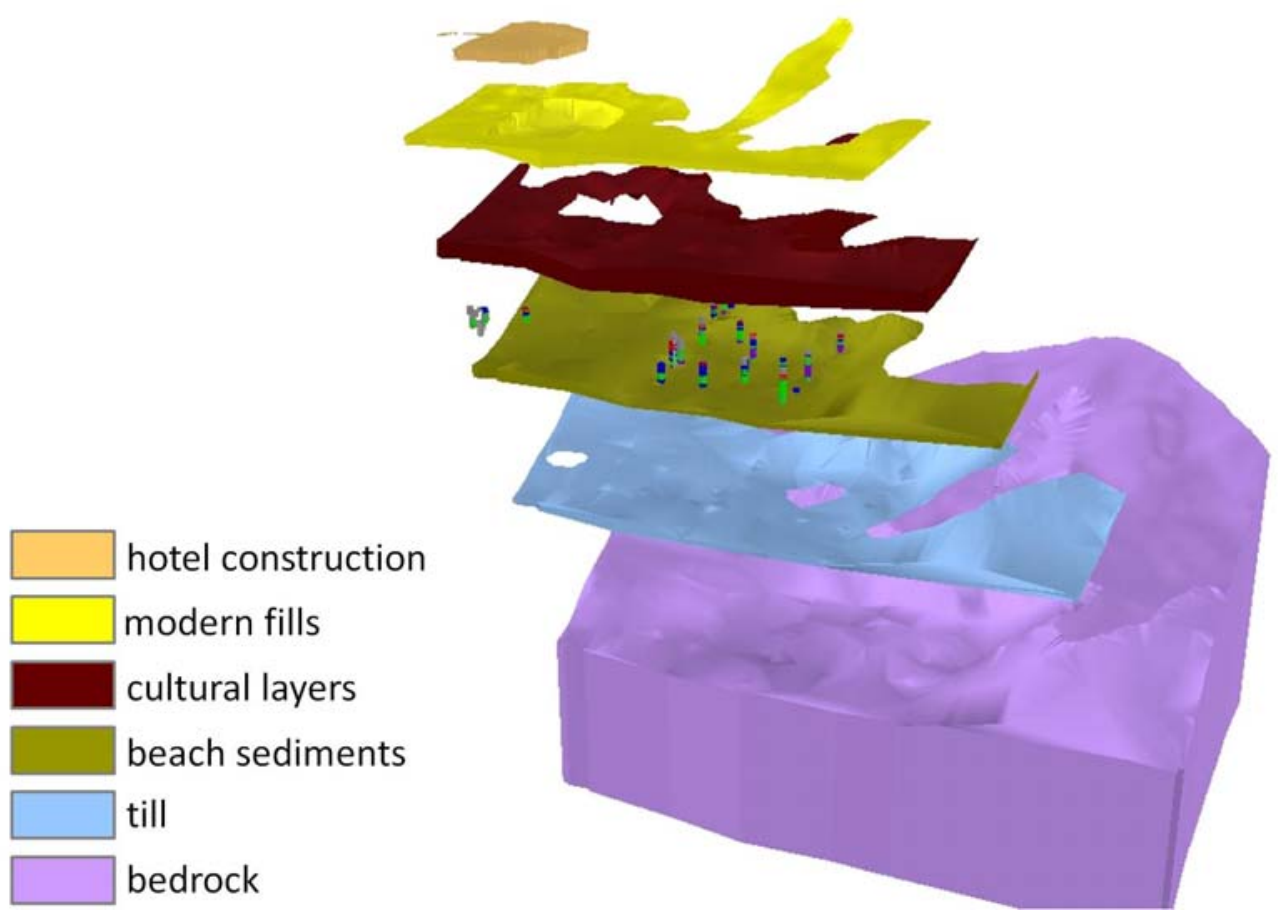

FIGURE 4: Exploded view of 3D subsurface model, including borehole sticks with attributes showing state of preservation. 


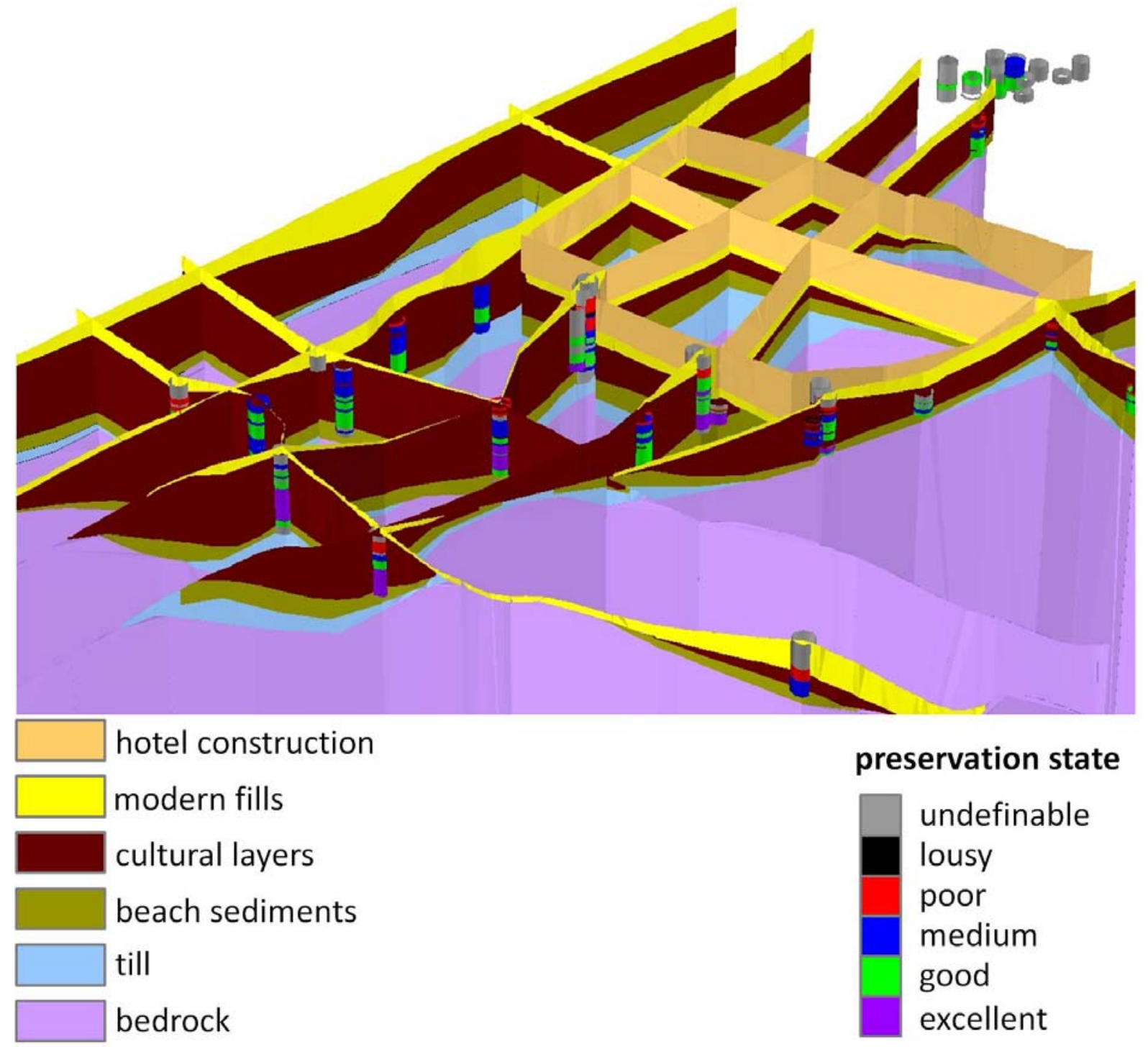

FIGURE 5: 3D section view with borehole-sticks showing documented state of preservation. 


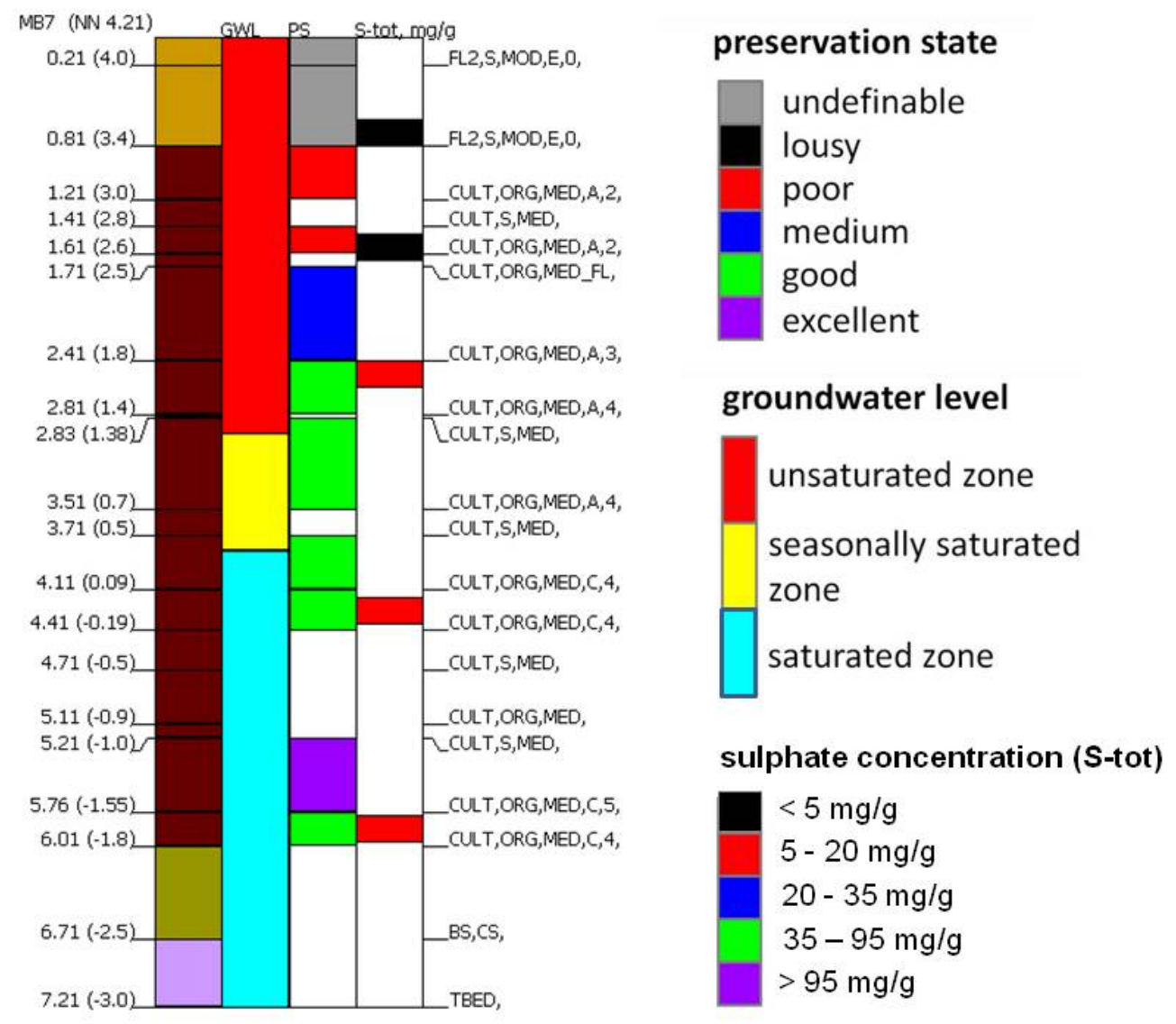

FIGURE 6: Visualization in the GSI3D borehole viewer, with categorized parameters for saturation condition, preservation category and chloride content.

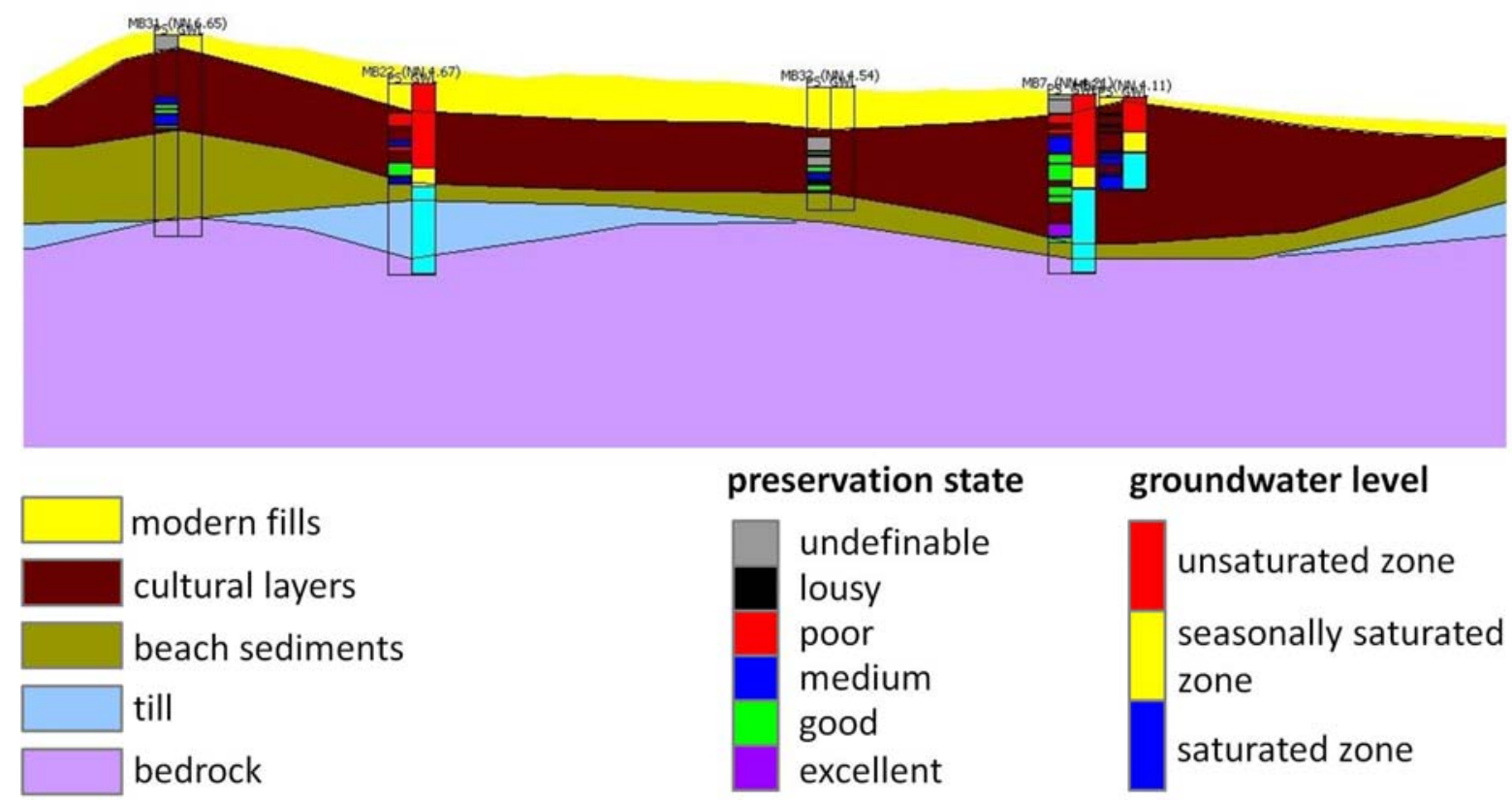

FIGURE 7: Part of a NW-SE section along Bryggen with borehole-sticks colour-attributed according to registered state of preservation and saturation conditions. 


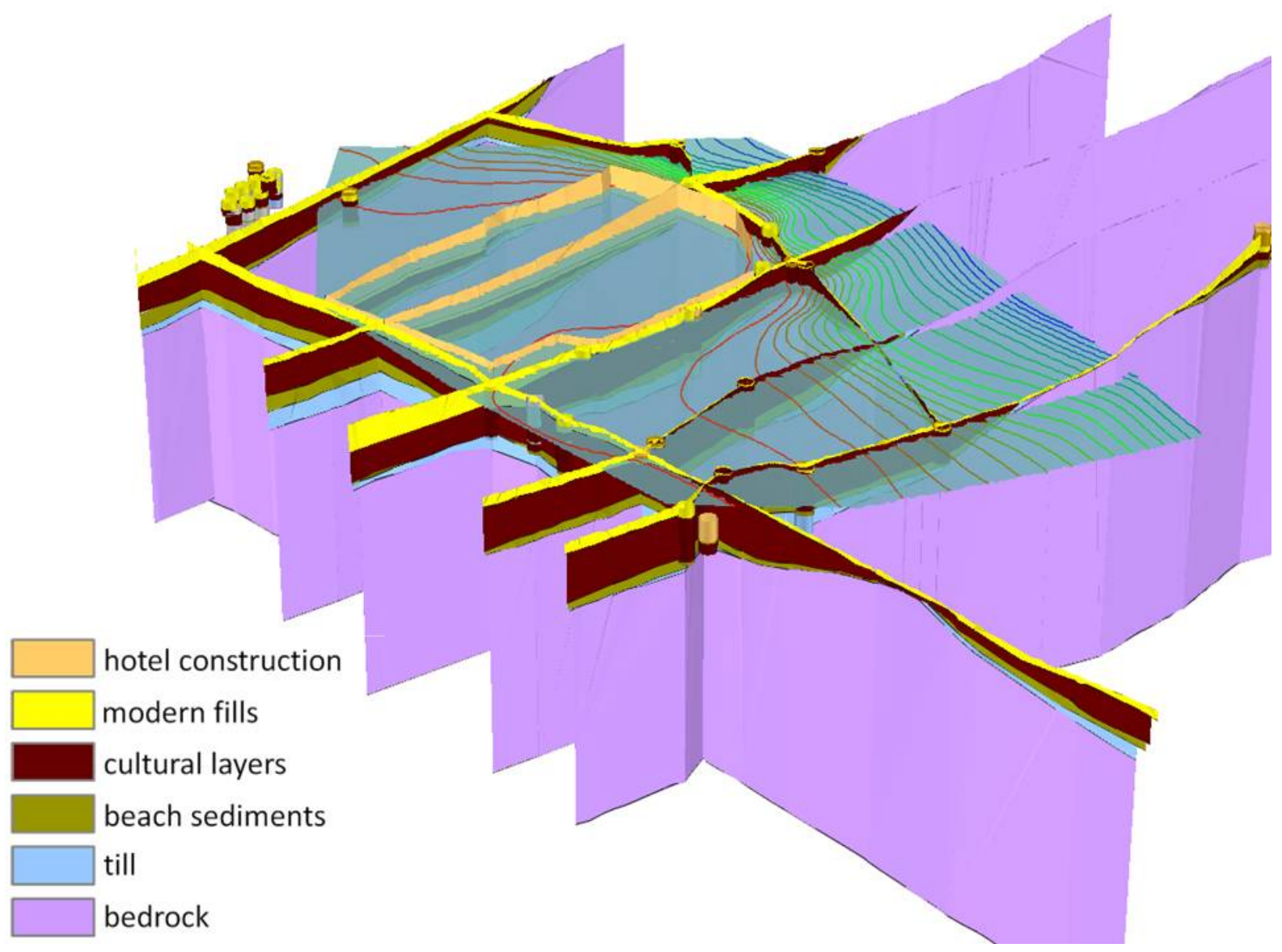

FIGURE 8: 3D section view with groundwater table (representative annual low)

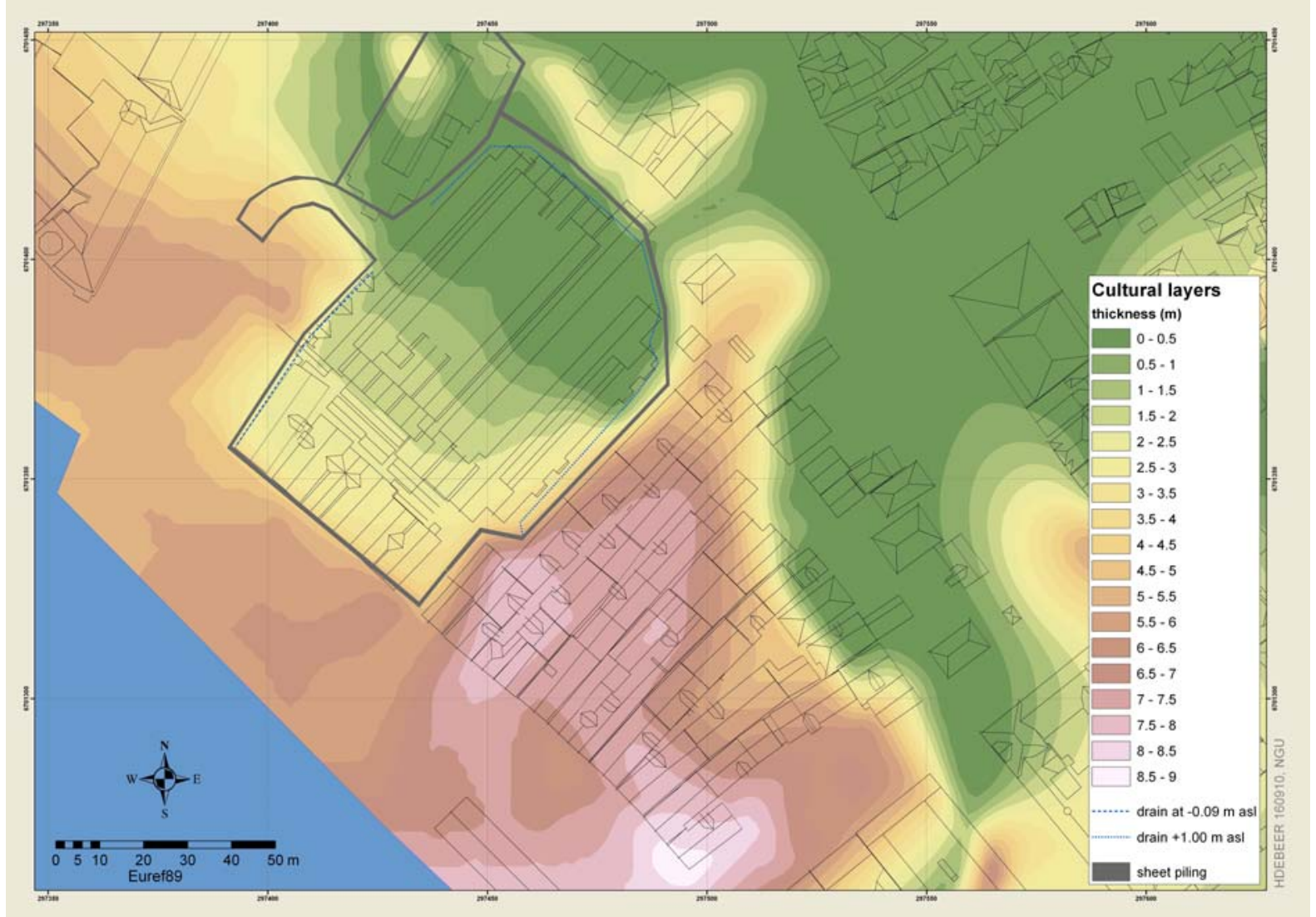

FIGURE 9: Thickness of the cultural deposits as calculated from 3D subsurface model. 

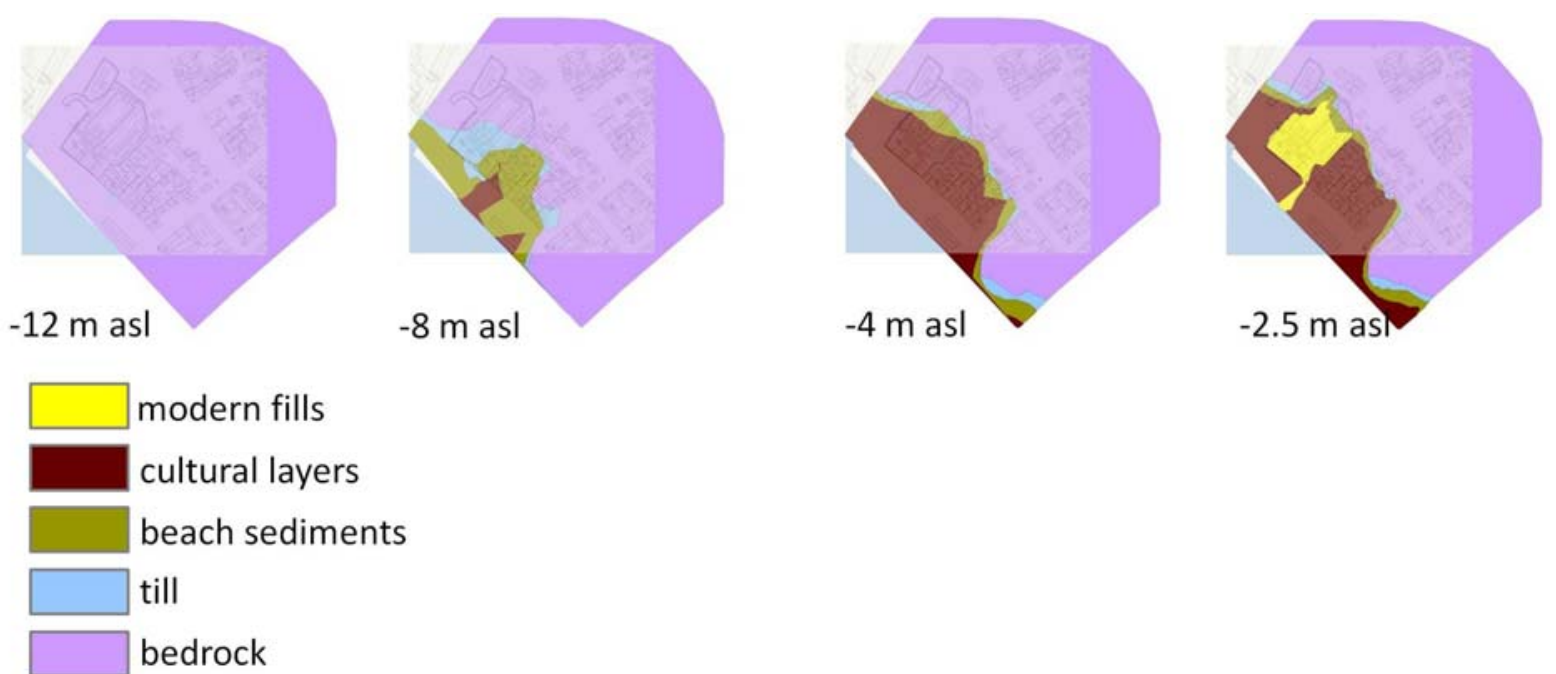

FIGURE 10: Synthetic surfaces (“geological maps”) at -12, -8, -4 and -2.5 m asl. 


\begin{tabular}{|c|c|c|}
\hline Class & Type & Unit \\
\hline \multirow{12}{*}{ Made Ground } & \multirow{3}{*}{ Engineered embankment } & road embankment \\
\hline & & flood defence embankment \\
\hline & &.. \\
\hline & \multirow{2}{*}{ Waste Tip } & mine waste tip \\
\hline & &.. \\
\hline & \multirow{2}{*}{ Raised fill } & land raising domestic refuse fill \\
\hline & & .. \\
\hline & \multirow{5}{*}{ Archaeological (raised) layer* } & domestic layer* \\
\hline & & maritime layer* \\
\hline & & agricultural layer* \\
\hline & & industrial layer* \\
\hline & &.. \\
\hline \multirow{11}{*}{$\begin{array}{l}\text { Worked } \\
\text { Ground }\end{array}$} & \multirow{3}{*}{ Engineered excavation } & road cutting \\
\hline & & canal cutting \\
\hline & &.. \\
\hline & \multirow{3}{*}{ Mineral excavation } & quarry \\
\hline & & mine entrance \\
\hline & &.. \\
\hline & \multirow{5}{*}{ Archaeological excavation* } & lime slaking pit* \\
\hline & & drainage ditch* \\
\hline & & ash pit \\
\hline & & dug well \\
\hline & &.. \\
\hline
\end{tabular}

TABLE 1: Selected examples of subdivisions under Made Ground and Worked Ground. Suggestions for archaeological classification are marked with * (modified after Ford et al., 2006).

\begin{tabular}{|c|c|c|c|c|c|c|}
\hline \multirow{2}{*}{$\begin{array}{l}\text { Position in relation to } \\
\text { groundwater level }\end{array}$} & \multicolumn{6}{|c|}{ Degree of preservation } \\
\hline & $\begin{array}{c}0 \\
\text { null-value }\end{array}$ & $\begin{array}{c}1 \\
\text { lousy }\end{array}$ & $\begin{array}{c}2 \\
\text { poor }\end{array}$ & $\begin{array}{c}3 \\
\text { medium }\end{array}$ & $\begin{array}{c}4 \\
\text { good }\end{array}$ & $\begin{array}{c}5 \\
\text { excellent }\end{array}$ \\
\hline Unsaturated zone $(\mathrm{A})$ & A0 & A1 & A2 & A3 & A4 & A5 \\
\hline Seasonally saturated zone (B) & BO & B1 & B2 & B3 & B4 & B5 \\
\hline Saturated zone (C) & CO & C1 & $\mathrm{C2}$ & C3 & C4 & C5 \\
\hline Fill, later than ca. $1900 \mathrm{AD}$ & Do & D1 & D2 & D3 & D4 & D5 \\
\hline
\end{tabular}

TABLE 2: State of preservation scale (SOPS), for archaeological layer recording (Norsk Standard, 2009) 